\title{
PENERAPAN EVALUASI KEPERAWATAN TERHADAP ASUHAN KEPERAWATAN DI RUMAH SAKIT
}

\section{Wanda Miftah Fatihah}

Email : wandamiftah22@gmail.com

\begin{abstract}
ABSTRAK
Evaluasi dalam keperawatan merupakan suatu proses yang dilakukan dengan cara melakukan identifikasi untuk melihat apakah ada dampak dari rencana asuhan keperawatan yang telah dilakukan. Dan untuk melihat apakah asuhan keperawatan yang telah dilakukan tercapai atau tidak. Sebagai perawat yang professional kita diharuskan untuk berpikir kritis pada proses evaluasi ini karna sangat penting dalam mencapai keberhasilan dari perawatan kepada klien
\end{abstract}

Kata kunci : Evaluasi Keperawatan, Tujuan Evaluasi, Perawat.

\begin{abstract}
Evaluation in nursing is a process carried out by identifying to see if there is an impact of nursing care plans that have been carried out. And to see if the nursing care that has been done achieved or not. As professional nurses we are required to think critically in this evaluation process because it is very important in achieving the success to give care to the clients

Keywords : Nursing Evaluation, Evaluation porposes, Nurse.
\end{abstract}




\section{Latar Belakang}

Keperawatan merupakan sebuah pelayanan yang bertujuan untuk melayani kebutuhan dasar, seperti meningkatkan, memperbaiki, mencegah dan melakukan rehabilitasi pada suatu individu dari suatu keadaan yang tidak normal (sakit).

Menjadi perawat yang
professional kita dituntut untuk memberikan pelayanan yang optimal dalam pemenuhan kebutuhan dasar kliem. Diperlukannya sifat yang telaten, asertif dan dapat berpikir secara kritis terutama saat melakukan evaluasi. Tahap evaluasi merupakan proses secara sistematis untuk melihat apakah ada dampak yang diakibatkan dari kegiatan sebelumnya.

Tahap evaluasi pada keperawatan merupakan tahap akhir yang berguna untuk melihat apakah rencana atau proses keperawatan yang telah dilakukan sudah berhasil secara optimal atau tidak.

Jika belum tercapainya tujuan dari tindakan keperawatan yang sudah dilakukan,, perlu dilakuinnya penyusunan ulang atau modifikasi rencana yang baru, modifikasi rencana yang baru kita lakukan atas persetujuan keluarga klien.

\section{Metode}

Metode yang dilakukan dalam penulisan kajian ini yaitu dengan membaca buku, menganalisis, serta mengeksplorasi dari referensi yang berkaitan dengan" Penerapan Evaluasi Keperawatan Terhadap Asuhan Keperawatan Di Rumah Sakit" melalui referensi yang berbeda, yaitu beberapa ejournal, tesis, yang didapat kan dengan memuat google scholar, pubmed, dengan memasukan kata kunci sesuai judul kajian.

\section{Hasil}

Berdasarkan kajian yang sudah dilakukan mengenai "Penerapan Evaluasi Keperawatan Terhadap Asuhan Keperawatan Di Rumah Sakit" dan didapatkan hasil dari beberapa referensi mendapatkan hasil bahwa evaluasi merupakan hal yang sangat penting dilakukan pada klien di rumah sakit, hal ini dikarenakan perawat dapat melihat hasil keefektifan rencana asuhan keperawatan yang telah dilakukan. 
Pembahasan

Secara umum, evaluasi diartikan sebagai proses yang dilakukan secara sistematis yang dilakukan guna untuk membandingkan apa yang sudah dilakukan pada kriteria sebelumnya (Wilkinson,2007).

Dapat disimpulkan bahwa evaluasi merupakan suatu hal yang berkelanjutan, direncanakan serta sistematis ( terarah).

Pada proses keperawatan juga ada yang namanya evaluasi, yaitu evaluasi keperawatan.

Menurut Nursalam (2008), Pada evaluasi keperawatan ini perawat dapat memungkinkan untuk memantau atau memonitor apa saja yang terjadi di proses keperawatan, seperti perencanaan, analisis, pengkajian, dan implementasi intervensi.

Evaluasi adalah langkah terakhir pada proses keperawatan, evaluasi keperawatan ini dilakukan untuk menandai apakah rencana keperawatan yang dilakukan pada pasien sudah tercapai atau sudah sesuai dengan perencanaan atau tidak.
Tahap evaluasi diterapkan dengan melibatkam tenaga kesehatan (perawat) serta pasien yang dirawat.

Bila setelah dilakukan evaluasi namun asuhan keperawatan belum atau tidak berjalan secara optimal, perlu dilakukan rencana keperawatan yang baru. Maka hal ini dapat dilakukan dengan bertahap sesuai dengan kesediaan keluarga pasien.

Evaluasi keperawatan memiliki beberapa tujuan, yaitu :

1. Melakukan hubungan antara klien dan perawat, melihat respon apa yang diberikan klien setelah dilakukan tindakan keperawatan yang telah dilakukan.

A. Jika klien sudah sesuai dan mencapai tujuan keperawatan sesuai dengan kebutuhan perawat dapat mengambil keputusan untuk mengakhiri rencana atau tindakan yang sudah dilakukan.

B. Jika klien sukar untuk mencapai tujuan keperawatan perawat dapat mengambil keputusan yaitu mengubah 
atau memodifikasi rencana tindakan yang akan dilakukan sebelumnya dengan yang baru.

\section{Jika klien mungkin} memerlukan waktu yang lama untuk mencapai tujuan keperawatan, perawat dapat mengambil keputusan yaitu meneruskan rencana tindakan.

Evaluasi memiliki beberapa komponen penting, antara lain :

a. Mengumpulkan bagaimana kriteria,pertanyaan evaluasi dan standar.

b. Pengumpulan data yang akurat mengenai keadaan pasien.

c. Membandingkan dan menganalisa data sesuai dengan kriteria dan standar.

d. Membuat kesimpulan dan merangkum tindakan.

e. Menerapkan tindakan keperawatan sesuai dengan kesimpulan yang didapatkan.
Evaluasi ada beberapa jenis, antara lain :

1. Evaluasi Proses ( Evaluasi Formatif)

Pada evaluasi proses (Formatif) ini perawat memfokuskan pada aktivitas apa saja yang telah dilakukan dalam proses keperawatan serta bagaimana hasil akhir dari aktivitas yang telah dilakulan dan bagaimana kualitas pelayanan tindakan keperawatan.

Metode yang dilakukan pada evaluasi ini adalah pengumpulan data analisis rencana asuhan keperawatan, obeservasi terhadap klien, pertemuan kelompok, adanya wawancara serta pengisian form evaluasi.

Pada evaluasi formatif ini harus dilakukan secepat atau segera mungkin setelah perencanaan dilakukan terus menerus sampai tercapainya tujuan.

Pada evaluasi ini juga perawat dapat menganalisis apa saja respon klien terhadap tindakan keperawatan yang telah dilakukan.

Contoh : pada tanggal 3 November 2020, Pada hari selasa telah dilakukan pendidikan kesehatan pada keluarga Ny.Y pada pukul 14.00, implementasi yang dilakukan dengan metode ceramah dan 
media brosus, belum sepenuhnya dimengerti oleh keluarga klien, diperlukan untuk mengubah metode lain yang lebih efektif

2. Evaluasi Hasil ( Evaluasi Sumatif)

Pada evaluasi sumatif ini, perawat memfokuskan pada hasil akhir tindakan keperawatan yang telah dilakukan pada klien.

Perawat dapat melihat apakah ada perubahan status kesehatan atau perubahan status di akhir tindakan.

\section{Penutup}

\section{KESIMPULAN}

Evaluasi keperawatan adalah suatu langkah yang dilakukan untuk melihat apakah ada dampak dan apakah rencana asuhan keperawatan telah mencapai tujuannya atau tidak.

Dan untuk menentukan apakah rencana keperawatan sudah efektif serta untuk menentukan rencana keperawatan klien selanjutnya, apakah rencana keperawatan dapat dilanjutkan dan apakah bisa di modifikasi dengan rencana asuhan keperawatan yang lain.

\section{DAFTAR PUSTAKA}

Adawiyah,R., Thamrin., \& Djafar,L. (2012). Evaluasi pelayanan yang diberikan oleh Perawat pada ruang kelas III Rumah Sakit Umum Daerah Dokter Soedarso. Jurnal Tesis PMISUNTAN-IAN. 1(1). 1-10.

Anggraini, D., Hakim, L., \& Imam, C. W.(2014). Evaluasi Pelaksanaan Sistem Identifikasi Pasien di Instalasi Rawat Inap Rumah Sakit. Jurnal Kedokteran Brawijaya, 28(1), 99-105.

Astuti, Y. D., Dewi, A., \& Arini, M. (2017). Evaluasi Implementasi Clinical Pathway Sectio Caesarea di RSUD Panembahan Senopati Bantul Busono, P. B. T. (2010). Evaluasi Penerapan Model Praktek Keperawatan Profesional di ruang Maranata I Rumah Sakit Mardi Rahayu Kudus . (Doctoral dissertation. Universitas Diponegoro).

Busono, P. B. T. (2010). Evaluasi Penerapan Model Praktek Keperawatan Profesional di ruang Maranata I Rumah Sakit Mardi Rahayu Kudus (Doctoral dissertation, Universitas Diponegoro). 
Gobel,M.G.S.,Mulyadi， \& Malara,R.T. (2016). Hubungan Peran Parawat Sebagai Care Giver Dengan Tingkat Kepuasan Pasien Instalasi Gawat Darurat di RSU. Gmibm Monompia Kotamobagu Kabupaten Bolaang Mongondow. E-journal Keperawatan (e-Kp) .4(2). 1-7.

Hariyati, R. T. S., Afifah, E., \& Handiyani, H. (2008). Evaluasi Model Perencanaan Pulang Yang Berbasis Teknologi Informasi. Makara kesehatan, 12(2), 53-58.

Mudayana, A. A. (2014). Peran Aspek Etika Tenaga Medis Dalam Penerapan Budaya Keselamatan Pasien Di Rumah Sakit. Supplemen Majalah Kedokteran Andalas. 37(1). 69-74.

Najihah. (2018). Budaya Keselamatan Pasien Dan Insiden Keselamatan Pasien Di Rumah Sakit: Literature Review. Journal of Islamic Nursing, 3(1). 1-8.

Rashvand, F.,Dkk. (2016). The Assessment Of Safe Nursing Care: Development And Psychometric Evaluation. Journal of Nursing Management, 1-15
Simamora, R. H., \& Fathi, A. (2019). The Influence Of Training Handover Based SBAR Communication For Improving Patients Safety. Indian Journal of Public Health Research \& Development, 10(9), 1280-1285.

Iriviranty, A. (2015). Analisis Budaya Organisasi dan Budaya Keselamatan Pasien Sebagai Langkah Pengembangan Keselamatan Pasien. Jurnal Administrasi Rumah Sakit. 1(3). 196-206. 